\title{
ANYBODY LIVING A PRIVATE LIFE IS A BELIEVER IN MONEY. GERTRUDE STEIN, THE GREAT DEPRESSION, AND THE ABSTRACTION OF MONEY
}

\section{Solveig Daugaard}

\section{ABSTRACT}

The article considers Gertrude Stein's reflections about the increasing abstraction of economics in response to the Great Depression and Roosevelt's New Deal in a number of explicitly political pieces from the mid-1930s, including "A Political Series" (1935), and her five brief newspaper commentaries on "money": "Money", "More About Money", "Still More About Money", "All About Money", and "My Last About Money" (1936). The article then relates them to Walter Benjamin's and Giorgio Agamben's ideas about the religious implications of the money system that resonate with Stein's salute to the "believer in money" as security against contemporary authoritarian tendencies. Stein's opinion pieces argue against taxation, unionism, and public spending, yet also demonstrate the slippery passage between her explicit conservatism, her economic liberalism and her still present radicalism and critique of patriarchal authority as they recycle crucial elements from contemporaneous works such The Geographical History of America (1935) and Everybody's Autobiography (1937).

\section{KEYWORDS}

Money, Gertrude Stein, The Great Depression, Capitalism as Religion, The 1930s, Infrastructural Poetics, Patriarchs, Modernism 


\section{EARNING MY FIRST DOLLAR}

In 1933, at the age of 59, the American writer Gertrude Stein published her first and only bestseller The Autobiography of Alice $B$. Toklas. This event is often framed as a turning point in her career, both in her own accounts and in the reception. And it can certainly be recognized as a turning point in her relation to money. In the sequel called Everybody's Autobiography (1937), she writes about her experience of finally making money on her writing:

When I was a child I used to be fascinated with the stories of how everybody had earned their first dollar. I always wanted to have earned my first dollar but I never had. I know a lot about money just because I never had earned my first dollar and now I have. ${ }^{1}$

Further, she accounts how she spent some of her "honestly made" money on a new eight-cylinder Ford car and a tailor fitted Hermès coat for her dog Basket-but quickly she goes on to meditate more profoundly on the question of money and how her experience of having finally made some on her writing had a destabilizing influence on this very writing.

Spending money was always a crucial component in Stein's life and a reappearing motif in her writings. And having a-fairly modest, but steady-income from her family inheritance was an indispensable factor for her renowned position as an essential art collector and social junction in the Paris avant-garde of the first third of the twentieth century. In his study about Stein and material culture, Michael Davidson notes that the emblematically Parisian figure of the flâneur, roaming freely in the public sphere of the modern city, is predominantly male in gender, but sociologists of market society like Thorstein Veblen have pointed to the way the bourgeois female consumer was becoming part of the modern leisure class of the same period. The female equivalent of the flâneur is the shopper. ${ }^{2}$ Davidson goes on to read Stein's most famous poetry collection Tender Buttons (1912) as a celebration of modern commodities and to engage with a series of early pieces by her that revel in the pleasure of shopping and spending money, including the repetitive group portraits "Flirting at the Bon Marche"(1911) and "Galeries Lafayette"(1911), both named after Paris department stores and depicting shopping as a pastime and a temporary comfort in more or less dreary lives. In spite of this, in Davidson's reading of Stein's radical materialist poetics, the critical notes against consumer capitalism weigh 
heavier than her celebrations of it. In contrast, Sianne Ngai, in reference to many of the same writings, has stressed how Gertrude Stein "unlike other avant-garde artists in [her] cohort [...] lacked antagonistic feelings towards consumer culture as such [...]" and was committed not just to the reproduction of consumer objects but also to the appropriation of the style of commercial language and the aesthetics of commercial imagery, in a celebration of the "positive affects" produced by commodity culture. ${ }^{3}$

Either way, there is no doubt that for Stein, as for many women of her time and class, the question of earning money was a lot more complicated than that of spending it. Elsewhere, I have suggested an infrastructurally oriented approach to Stein's relationship to the modern publishing economy by looking at the literary portraits she wrote throughout her career as texts that constituted their own infrastructure of distribution. ${ }^{4}$ The hundreds of portraits Stein wrote of friends and foes in the avant-garde circles of Europe and America had their own circulation inscribed in them, they were at the same time literary artefacts and gestures that performed a relation between Stein and her subject. Not only did Stein's portraits like other avant-garde poetry of the early 20th century testify to modernism's representational crisis and break with formal conventions to make form and content intertwine in new ways, they also applied an infrastructural poetics, making the distribution an integrated part of the artistic material on equal terms with the linguistic material and the subject matter. The portraits tied their subjects to Stein's circle, to her salon, and in turn the portrayed subjects were motivated to publish or otherwise distribute their own portraits in particular and Stein's work in general. These small scale file-sharing processes often melted into regular publishing: the dynamic art patron Mabel Dodge had her portrait exclusively printed and passed around in the society circles of New York; T.S. Eliot, although no advocate of Stein's writing, agreed to publish her portrait of him in The New Criterion; the art critic Henry McBride lobbied to have the fairly abstract "Have They Attacked Mary He Giggled. (A Political Caricature)" (1917) that mentions his name published in Vanity Fair. In this way, Stein's work in the 1910s and -20s to a wide extent circulated either independently of-or tapping sideways intothe capitalist literary publishing economy, in a way that comes closer to a moneyless barter economy or exchange economy than to an abstract monetary economy. Thus, in Stein's case any consideration of the relationship between money and literature, between the economic and the aesthetic sphere, must keep in mind 
this quite particular integration of infrastructures of distribution into the aesthetic product itself.

After 1933, when Stein made her first dollar, a lot of things changed. She returned to the United States on a highly publicized lecture tour, after 30 years of absence. She ventured with the large commercial publisher Random House, who published a number of her works in large print runs during the 1930s and -40 s. She also started to write in more directly communicative genres, i.e. newspaper commentary, some of which I will address in the following. She was suddenly a full-blown member of the modern literary economy. Much Stein scholarship stages this as Stein's Fall of Man, the point when she was torn away from her self-sustained sanctuary of exclusive, experimental art for art's own sake, and all of a sudden started to worry about an audience, and about being seen, loved, and paid for. From having a secure sense of the "real value" of her work, Stein suddenly experienced her work, and herself along with it, as having an exchange value, which, as Luke Carson has suggested, resulted in "the chiastic confusion of inside and outside that results from the circulation of the commodity on the market."5 The logic of deflation implied in this narrative has established a hierarchy of sorts in the oeuvre, where her earlier, more playful work written before this "fall" and breaking radically with conventions of grammar and syntax is often valued higher and ascribed more weight than the work adapting a more immediately accessible language and directly addressing a broader audience, with the result that the latter has been, at least to an extent, ignored or conceptualized as some sort of exception that can be disregarded.

\section{THE WANDERING OF MONEY AND WORDS}

In the following, I will address some of Stein's briefer texts from the mid-1930s, all of them attempts at concrete political commentary, and all centred on economic issues. At the centre of my concern is "A Political Series" which was written in 1935 but published posthumously (in Painted Lace, 1955), "The Capital and Capitals of the United States of America," published as the first piece in a series about America that Stein did for The New York Herald Tribune in 1935, and the five texts about money she wrote for the Saturday Evening Post in 1936 called "Money," "More About Money," "Still More About Money," "All About Money,” and "My Last About Money." Although they have attracted some attention in recent years among scholars interested in the relationship between modernism and the marketplace and between art and the 
economic crisis of the 1930 s, ${ }^{6}$ these texts are all among the more rarely discussed in Stein's total oeuvre.

My readings will be informed by an outlook to some of Stein's other widely distributed writings from the same two years, including titles she had published by Random House such as the aestheticphilosophical meditation The Geographical History of America Or the Relation of Human Nature to the Human Mind (1935). While this is among the most discussed of Stein's later works, it has been considered most widely for its playful insistence on the freedom from convention, memory and identity of the wandering unit of consciousness Stein calls "the human mind.” A figure that, in various shapes and under different names, is tied both to the exiled artist and to a promiscuous, female, and queer sexuality throughout Stein's writings, and which has been widely influential in feminist, queer, and post-colonial theory, inspiring for instance Rosi Braidotti's concept of the nomadic subject. ${ }^{7}$ Meanwhile, The Geographical History's direct replay of some of the most controversial themes running through the series of newspaper commentaries-such as Franklin D. Roosevelt's economic policy and the free movement of capital-has not been addressed as much, nor has it been connected to the work's extensive meditations on the equivalence between a semiotic and a monetary economy-between the workings of words and money-and the simultaneous opposition proposed between what is termed "literary thinking" on the one hand and "governments and propaganda" on the other. I will follow some of these trails through the winding prose patterns of The Geographical History in order to elaborate on the way Stein's radical economic liberalism affects her infrastructural poetics and shapes her meditations on words and money, relating them to thoughts by Walter Benjamin and Giorgio Agamben about the religious implication of money as a system of value based exclusively on the belief of its worshippers, what Stein calls "believers in money."

\section{COMING HOME FOR THE DEPRESSION}

Besides being written after Stein made her first dollar, when her relationship to money and publicity arguably had changed, the commentaries are also texts that respond to Stein's experience of revisiting an America that had changed during her many years abroad. First of all, she had not been around to witness the culmination of the transition to a free market economy and the rapid industrial expansion that had taken place in the first decades of the twentieth century, introducing mass production, mass labour, and, eventually, mass consumption that was 
growing exponentially up until the stock market collapse of 1929. And then, when Stein arrived in 1934 it was to an America in the middle of the Great Depression. The lightness of her tone in these writings makes it easy to forget that they are coming out of, and addressing, an experience of severe crisis that was prevalent in the 1930s. While post-war popular conceptualizations of World War II and its immediate prelude often promote a narrative of the solid capitalist democracies led by the United States defeating decadent, fascist regimes, it is important to remind ourselves that the global political situation in the 1930s was a lot less clear-cut to the people living in it.

As Enzo Traverso has suggested, in Europe following World War I, a historical coupling of liberal democracy with "total war" gave birth to totalitarian political ideas, which were "the outcome of a process of brutalization of politics that shaped the imagination of a whole generation." As we shall see, in Stein's writings from the 1930s this experience of a democratic society somehow infected by an authoritarian logic belonging to warfare takes its own distinct forms. Contrary to the dichotomy produced in the post-war era that constructs American free-market capitalism as an antidote to totalitarian tendencies tormenting Europe in the 1930s, Stein saw authoritarian tendencies in the democratic America of the Great Depression similar to what she had seen of German and Italian fascism and of Russian communism. Thus, this historical context remains an important factor to be reckoned with when considering Stein's concern for the fate of the American economy and democracy in these texts.

Luke Carson has identified the growth of mass consumption as a fundamental change in American economy of the 1930s to which modernists like Ezra Pound and Gertrude Stein reacted. In Carson's analysis Pound and Stein share an ambivalence towards the relinquishment of scarcity as the cultural foundation of the economy. In 1933, president Roosevelt abandoned the Gold Standard in order to secure the country's economic recovery, a move that hit Stein's personal finances, as it reduced the income of her family's investments by 40 percent. ${ }^{9}$ For Stein, this came to mark the shift from an economy founded in the solidity of gold, to an abstract economy of paper money that she had difficulties understanding and accepting. As Bryce Conrad puts it "she realized that there was a distinction between [...] currency in its nineteenthcentury pre-Gold Standard sense-and [...] speculative capital of the sort wielded by the corporate interests that had defined market economics during the period of her 30-year absence.”10 
In a brief commentary, Giorgio Agamben has emphasized the date 38 years after Roosevelt's resolution, when president Nixon demolished the last remaining connection between the American dollar and the country's gold reserve, as the point in history that once and for all turned money into a self-referencing system of credit that does not refer to anything outside of itself. Agamben points to this moment as a consolidation of Walter Benjamin's analysis from his 1921 fragment "Capitalism as religion" that is of critical importance to Agamben's own project of uncovering the substructures of "the governmental machine of the West"11 through an analysis of the theological paradigm of economy and government. In this rather sketchy fragment, Benjamin suggests that capitalism is essentially to be considered a religion. And Agamben claims this analysis to be fulfilled with the abandonment of the dollar's connection to gold-since the monetary system is then based exclusively on the belief of its worshippers. ${ }^{12}$ It is striking how the economic transformation experienced rather abruptly by Stein in the 1930s-much closer in time to Benjamin's fragment-presents itself as a significant antecedent to Agamben's 1971 moment, already carving out this route towards the escalating abstraction of capitalist economy, and as we shall see Stein's experience of the new economy has its own relation to the theological paradigm suggested by Agamben.

\section{GETTING RID OF MONEY OR LETTING CAPITAL WANDER}

Ezra Pound was equally concerned about money moving beyond understanding and control. He was generally convinced by the Marxist analysis that the capitalist economy would eventually break down from the falling rate of profit and the following decrease of wages, but profoundly unwilling to draw a Marxist conclusion. While he mourned the destruction of society, culture and community caused by the liberal marketplace he did not support the workers' overtaking of the means of production as in Russia. Instead, in his ABC of Economics (1933) Pound turned to Mussolini for a solution to modernity's problems and suggested that the monetary system should be controlled by the fascist sovereign in order to regulate the borders between the private, economic sphere and the public, political sphere, borders that are increasingly blurred in modernity's rise of mass culture. ${ }^{13}$ Although the perceived challenge to American economy was similar for Pound and Stein in the early 1930s, their approaches were fundamentally different. Stein's “A Political Series” is her reflection on Roosevelt's leadership and his New Deal as a 
dangerous political initiative threatening to do away with money by overspending them. Here she asks:

Would it be possible to get rid of money by making it foolish by making it cease to have any meaning by piling up the figures about it so that it ceases to have any reality. ${ }^{\mathbf{1 4}}$

The text is constructed around an analogy between the two American Roosevelts, Franklin D. and his distant relative and presidential predecessor, Theodore, and the two French Napoleons, as equally disastrous figures for their respective countries. It rhetorically asks whether getting rid of money is indeed the strategy behind Roosevelt's wide-spanning economic and social program, or if he is just "electioneering" - that is, trying to feed everybody so that they will re-elect him.

Stein's argument here assumes a scarcity economy. As she argues, the monetary system works only when there is a certain scarcity; if everyone has enough money, money will lose its value. The subject of counting often pops up with Stein. Appearing for the first time in her monstrous novel, The Making of Americans (1906-11), is her recurring idea of "counting everything by one and one and one.” 15 Years later, in one of her 1934 touring lectures, Stein returns to the issue of counting, and its connection to her crucial understanding of repetition in her own writing as always "insistence," due to the intense attention paid to each instance in the writing being written or the story being told: "After all the natural way to count is not that one and one make two but to go on counting by one and one and one.” 16 When this principle of repetition that comes from the semiotic economy of recounting stories and repeating sentences is applied to the financial economy of counting money it constitutes an antithesis to Roosevelt's practice of spending money by "piling up the figures about it so that it ceases to have any reality."

A critique of monetary instrumentality combined with an ambivalent sense of equivalence between money and writing can be traced back to Stein's writings from the 1920s. The poem "Business in Baltimore" (1925) is based on Stein's youth in Baltimore, where she, orphaned at the age of seventeen, came to live with her mother's relatives who ran a successful merchant and banking business. It was Stein's Baltimore banker cousins who for the rest of her lifetime managed the paternal inheritance and paid out the monthly income to her and her siblings. In the poem, she playfully couples monetary value with patriarchal structuring 
of romance, marriage, and family life-all the institutions she herself escaped through her Paris exile-while twisting and repeating the vocabulary of business and bourgeoisie to the point of its deflation into monotonous word sequences which become little more than abstract surfaces of print on paper. The concrete materiality of the writing instantiates and reinforces the abstraction of the economic paradigm.

As Michael Szalay has suggested, Stein's concern about Roosevelt "trying to evacuate money of meaning" by overspending it in his New Deal resembles the accusations she faced from conservative contemporaries against her own linguistic style, especially in repetitive pieces like "Business in Baltimore," as "trying to evacuate the English language of meaning."17 Stein's most characteristic stylistic feature, her repetition, is what apparently comes closest to this strategy of overspending. Yet, Stein's repetitions-or insistencies-are informed by a way of counting that does not derive from the same source as the counting of Roosevelt or of her Baltimore banker cousins. In fact, when living in Baltimore, Stein did not spend her days with her banker cousins and uncles. Rather, as she recounts in her lectures, she sat around with her little gossipy aunts, from whom she not only learned that there was no such thing as repetition, as long as the speaker was "talking and listening at the same time"18 but also realized for the first time that "the natural way to go on counting is by one and one and one."19 Thus, although Stein is clearly anxious about unreal sums of capital sabotaging the scarcity principle of the "old" patriarchal economy she knew and resisted, but also depended on, in the realm of poetry she can count freely like her little aunts, and exploit the essentially feminist strategy of poetic overspending in an anarchist undermining of the power of "Patriarchal Poetry," as the title of her 1927 long poem goes.

In "A Political Series" Stein describes the approach of Roosevelt as not only patriarchal but also highly un-American and ascribes his election to a profound identity crisis in American society after World War I where people have become accustomed to obeying orders and submitting to authority. As in Traverso's analysis, Stein identifies in the American public a tendency to obey as soldiers do, calling out contemporary American democracy as a system subjected to the same damaging sort of paternalistic organization as that of war. In Stein's highly idiosyncratic analysis, Roosevelt with his New Deal policies is reacting to the Depression, but, like his predecessor, he is acting without any sensibility for the American way: 
When I say Theodore and Franklin Roosevelt are not American I mean they do not feel America to be a very large country around which anybody can wander and so although a government is there it is not always anywhere near but they feel it to be a little country which they can govern, and so it is European and not American. ${ }^{20}$

So, Roosevelt acts as if America is a little country that can be governed and not-as it is in truth, according to Stein-a large country in which you "can wander."

This particular trait in American culture was one that Stein herself immensely appreciated. As she explains in "The Capital or Capitals of the United States of America" written earlier the same year, in America, unlike most other "important countries," the capital is not in the country's most important city, nor are any of the state capitals placed in the largest or most important city of this or that state. This is so, she claims, because in America important cities can wander the same way money wanders. But government tends to stay. America is a country in which to wander, and therefore Americans hardly need their capitals, and certainly would rather not see too much of them.

This freedom of infinite movement, this liquidity, is a crucial value in Stein's oeuvre from her earliest to her latest writings. In all of her aesthetic meditations it is implied as an ideal for art and literature. In her lengthy aesthetic-philosophical meditation The Geographical History of America Or The Relation Between Human Nature and the Human Mind, it is tied to the freedom of the "human mind" conditioned by the flat land of the American landscape that enables the physical mobility and by the faculty tied to language and writing as art, or "master-pieces" that enables mental mobility. These qualities are opposed to the fixed perspective of "human nature" which is tied to utility, memory and identity, and to the attributes of organizations such as governments and propaganda: "no there is no government where the land is flat. / There should not be. / And there is not. /And why not. / Because anybody can wander and if anybody can wander then there should not be any human nature."21

Throughout the liquid aesthetic meditations of The Geographical History, the stark contrast between political organization and the wandering of the human mind seems remarkably stable. The universal importance of money for any pleasurable existence is introduced in the first pages, in the characteristic self-interrupting deductive prose style of this work: "Now anybody who loves money 
and anybody who loves loves money anybody who loves loves to have money" 22 unsentimentally linking the concept of love to the love of money. However, the relationship between the human mind and money remains elusive. As suggested earlier, there appears to be an immediate correspondence between Stein's ideal liquidity of the human mind and the liquidity of the free roaming finance capital no longer held down by the Gold Standard, the government, or any other material anchor:

Flat land is not romantic because you can wander over it and if you can wander over it then there is money and if there is money then there is the human mind and if there is the human mind there is neither romance nor human nature nor governments nor propaganda. ${ }^{23}$

As also suggested in "A Political Series" and "The Capital or Capitals" in America, according to Stein, the ideal of the anarchic liquidity of capitals as seats of (minimal) government is the mirror image of the liquidity of capital as money in the free market, and when things can wander, no organization is needed. It is pertinent to note how the dynamics of this liquidity tied to the American landscape recalls the unending deterritorializations of capitalism as they are depicted by Deleuze and Guattari in their writings on Capitalism and Schizophrenia: that is, the ability of the capitalist economic paradigm to always make a market out of something that was not a market before. In turn, the same quality is also tied to the practice of writing as an art form-to the making of "master-pieces":

Ordinarily anybody finishes anything.

But not in writing. In writing not any one finishes anything. That is what makes a master-piece what it is that there is no finishing. 24

And yet, the place of money in The Geographical History remains ambiguous, suggesting money and language as reinforcing each other in their shared fate as self-referential systems no longer able to reach an object outside of themselves: "Money is what words are./ Words are what money is" but immediately the suggested equivalence between semiotic and monetary economy turns into a question: "Is money what words are / Are words what money is" 25 which seems, in a way, to exhaust the potential of this parallel for Stein. The meditation returns to the question of defining money, 
repeatedly by way of Roosevelt's overspending as described in "A Political Series." Unlike government, war, and politics, but like master-pieces, money is "not finishing," but it is also differentiated from master-pieces: "What is money and what is romanticism it is not like human nature because it is not finishing it is not like a master-piece because it has no existing." 26 The factor separating the abstract value of money from the abstract value of masterpieces is its reality. Money, in the end, is like romanticism, not concerned with or tied down by physical reality. This unreality inherent to (Stein's conception of) money once again recalls Benjamin's text on religion of money. But unlike money, masterpieces in Stein's meditation do exist in the physical world and art is thus kept out of the realm of religion.

\section{WHO SETTLES A PRIVATE LIFE?}

In "A Political Series," the only bulwark Stein can think of against being governed is the freedom to live "a private life." The concept of a "private life" was first featured in Stein's 1927 opera libretto Four Saints in Three Acts, written five years ahead of making her first dollar, but which premiered on Broadway in 1934, becoming a surprising audience success just months before Stein's return to America. Early in the first act, the lead saint, Saint Therese, repeats the question "Who settles a private life" 27 five times, as her character quadruples for the first time out of many in Stein's opera which is notorious for its explosion of the dramatic character. Early representatives of the wandering of the human mind, Stein's secular saints are free-roaming and multiple, they have no family, certainly no fathers, whether earthly or divine. Conceived only a few years after Walter Benjamin's fragment, they recall the religious cult of capitalism as they too have "no specific body of dogma, no theology" 28 and are relieved of narrative progression. Like it, they are immersed in permanent, enduring movement not directed towards any type of resolution. But quite unlike the path to destruction from the infinite burden of guilt and debt that emanates from this condition in Benjamin's explicitly Marxist fragment, Stein's saints appear without guilt, sin, obligations, or debts. They roam freely across the "landscape" of the stage in various constellations joining voices into a choir and splitting out again. Although their names often evoke landscapes, convents and cities, the saints never settle, except to the peaceful, unspecified but continuously ongoing "private life" of the nomadic wanderer.

In "A Political Series," the idea of a private life is presented in opposition to the paternalistic government, yet here Stein also 
suggests an immediate source for the concept, which, somewhat surprisingly, appears fairly patriarchal in nature: "As Robinson Crusoe's father said to him the pleasantest state of man is to be neither rich nor poor and to remain in enjoyment of a private life." 29 This bourgeois ideal of a middle ground of appropriate riches-derived not only from the foundational work of the bourgeois European novel in its most masculine incarnation, but even taking at face value the advice of Robinson's father-becomes the precondition of the private life that immediately ties it to the ideal of privation, of scarcity, that was also defended in the "Money" texts:

What is a private life.

Well I guess you may say roughly that a private life is when not everybody is being fed.

A private life and money I suppose do go together and if there is no money there is no private life and if there is no private life there is no money and sooner or later the Barbarians come and enslave everybody. ${ }^{30}$

What defines a private life, then, is not just money, but believing in money as it appears in a free-roaming market, preferably not regulated by governmental interference:

anybody living a private life is a believer in money and therefore a barbarian and the barbarians are always strong and those who are fed are always weak. You cannot be strong if you do not lead a private life. ${ }^{31}$

Like in Agamben's reading of Benjamin's fragment, capitalism is a religion because its system of value is based on the belief of its worshippers, the "believers in money." This quasireligious implication of a private life is already suggested by its importance to the saints of Fours Saints in Three Acts. But if the nomadic freedom of movement still appeared to function without restrictions or deficit in 1927 when Stein wrote her libretto, restrictions seem to have been enforced upon this freedom by the time she produced the 1930s commentaries.

\section{MONEY OR FATHERING}

The patriarchal nature of the monetary system was always well recognized by Stein, and, as Ulla Dydo has observed: "However free Stein's thinking about art, whenever wills and property enter, her ideas take patriarchal forms.”32 Accordingly, when confronted 
with the crisis economy of the 1930s, the only alternative to the prodigal father promising to feed everybody that Stein is able to come up with is another father. As she speculates in "Money":

if there was any way to make a government handle money the way a father of a family has to handle money if there only was. The natural feeling of a father of a family is that when anybody asks him for money he says no. Any father of a family, any member of a family, knows all about that. ${ }^{33}$

This restraining "no" of the family father not only clashes frontally with the repetitive, reproductive "yes" of Stein's femininely gendered literary thinking, to which I shall return shortly, this line of reasoning also brings us to the most controversial and violently debated issue in Stein's life and work and the end of the line for her anti-patriarchal sentiments. A direct lineage can be drawn from this speculation made in 1936 to the content of the speeches by Maréchal Pétain of which Stein commenced (but never completed) her translation in 1941. In his public speeches, Pétain is taking the role of the restraining father, demanding sacrifice, duty, and discipline of the French people in times of severe crisis. In the extremely exposed and vulnerable situation Stein was in when living in Vichy France, this protective, paternal voice possessed a certain appeal.

The "Money" texts negotiate these tendencies in Stein's oeuvre in an explicit, light-hearted, almost indiscreet way: starvation, colonialism, and inequality are the directly stated, and not particularly bewailed, costs of the money economy, which of course had little personal consequence for Stein at the time she was writing. As such, although far from totalitarian in its observation, Stein's thinking displays its own version of the brutalization of politics of the 1930s identified by Traverso.

Then again, Stein had her own frailties in relation to the paternalistic financial power. As she reminds us in "All about money": "The queen was in the parlor eating bread and honey the king was in his counting house counting out his money." 34 As a rule, women, including Stein herself who broke so many boundaries in her life, were not allowed into the heart of the economic sphere. Money is the warrantor of female freedom and enjoyment but at the same time the property of the patriarch. In a time of too much fathering Stein defends the autonomy of the market as a crucial principle to secure her freedom of mind and body-yet, she knew very well, that even money comes with strings attached. 
In the "Money"-series Stein's liberalist commentary becomes gradually more cynical: the first piece repeats the concern about a dangerous feeling of the unreality of money driving the politicians to overspending. "More about Money" ponders the dilemma that the British parliament was established to keep the king from spending too much money, but in America there is no institution able to stop congress from spending. "Still More About Money" makes an argument about the horrible consequences of government welfare programs, arguing that unemployment benefits makes the work force lazy, and then nothing will get done, and is topped with an elaboration of cultural prejudice against the Indo-Chinese, the nationality of the servant that Stein and her partner Alice Toklas had currently employed in their Paris household, since they had "given up trying to employ french people, those who were not working were unemployed and that was no way of changing them back to work." 35 "All About Money" claims money is the one feature to differentiate man from animal, and once again repeats the scarcity argument. The monetary system will only hold if you count the money by one and one and one, instead of throwing around large, abstract sums that make no real sense to you. "My Last About Money" could have been authored by any present-day neoliberal politician stating as it does the familiar argument that too much redistribution of wealth in terms of taxation and welfare programs for the poor will kill initiative and progress: we need the rich in order for society to function because if we get rid of the rich, we will all be poor. And finally, it presents an explicit defence of colonialism as necessary for the capitalist expansion that was powered by the desire for "individual liberty" of the eighteenth and nineteenth centuries, but which unfortunately can no longer be satisfied due to the lack of new territory to colonize: "The virgin lands are getting kind of used up, the whole surface of the world is known now and also the air, and everywhere you see organization killing itself by just ending in organization.” 36 But the most severe challenge to contemporary society, according to Stein's political analysis, is the way taxation and labour organization prevents people from thinking for themselves:

the other day a very able young man, you would not have expected he would feel that way about it, wrote to me and said after all we are all glad to have Roosevelt do our thinking for us. 37 
This point emphasizes the profound contrast between the solution suggested by Ezra Pound of having the fascist sovereign control the currency and the one suggested by Stein, as it brings her to her repeated critique of the patriarchal politics she sees as on the rise in the 1930s. When returning to America after 30 years of exile, Stein encountered an ambience resembling the one she experienced in the European countries prone to fascismpeople submitting willingly to the father figures of "Hitlerism and Fascism and Rooseveltism." 38 This is the same pattern she in Everybody's Autobiography connects to depression, both as a psychological condition and an economic one:

Everybody nowadays is a father, there is father Mussolini and father Hitler and father Roosevelt and father Stalin and father Lewis and father Blum and father Franco is just commencing now and there are ever so many more ready to be one. Fathers are depressing. ${ }^{39}$

This motif of Roosevelt, the father figure "doing our thinking for us" gets a twist in The Geographical History where Stein explicitly suggests a literary and feminist alternative to the presidential patriarch: "I tell you it is true that I do the literary thinking for you." 40 The following passages circle around the patriarchal organizing of society, returning time after time to the problematic figures of the Roosevelts and the Napoleons: "But you know I know that if a boy is to grow up to be a man what is the use./ Theodore and Franklin Roosevelt and Napoleon and Louis Napoleon."41 Clearly, the patriarchal organization following from war addressed in Everybody's Autobiography is also of concern here, where it reproduces itself via the paternal lineage and through military authorities. The alternative presented is feminist and aesthetic:

[...] why is it that in this epoch the only real literary thinking has been done by a woman.

Yes please think of something.

That is it.

Please think of something. And so no need of going around, because the scenery is there, not a storm, soldiers are not a storm, they look like it they look like not a storm, if anybody salutes you and respects you that is like a storm, and so in this epoch the important literary thinking is done by a woman.

But yet yes.

By no means cease. 42 
The scenery of respectful soldiers, the little boys who will inevitably grow up to be men obeying orders, is here met by the “important literary thinking [...] done by a woman," presenting an alternative truth to the one based in organization and paternal authority. Rather than being (merely) a megalomaniac gesture of Stein, the self-proclaimed genius, it suggests an aesthetic course based on the free participation of the other: "Yes please think of something/That is it." Stein places the open space to be filled out by her audience at the affirmative centre of this crucial passage, recalling once again the simultaneous talking and listening of her counting aunts. And in this gesture, which is more than just a rhetorical apostrophe, she is arguably also continuing the infrastructural poetics initiated by the portraiture and the salon in the first years of her career, into a more wide-ranging literary economy, as she once again places the social at the core of the aesthetic, and instead of delivering a formulated message calls out her new readers-a potential mass audience rather than the salon context's personalized address_to spread out and "think of something."

\section{NOT A POLITICAL WRITER?}

In “A Common Sense,” her essay on Gertrude Stein's 1932 Stanzas in Meditation, the poet Lyn Hejinian draws on Hannah Arendt's concept, "space of appearance." In Arendt's thinking, this construction signifies the space where "men" appear in relation to each other in word and deed, as Hejinian puts it, "it is the place where we know each other and know we are together." $\mathbf{4 3}$ Derived from the Greeks, from the public sphere of the polis, it is the common ground of free men where they are together and can participate in mutual deeds relieved from the immediate necessities of fundamental sustenance that belongs to the household. The space of appearance in Arendt's philosophy is the point of departure of politics.

But, claims Hejinian, "Gertrude Stein was not a political writer"44 and thus she reverses Arendt's concept when relating it to Stein. To Stein, the space of appearance was never in the public sphere, she holds, but always in the private sphere "Gertrude Stein was, for all her interest in genius and masterpieces (i.e. in authority), an advocate of the household sphere." $\mathbf{4 5}$

Hence, Hejinian argues that the freedom from the immediate material reproduction of life that the Greeks placed in the polis, Stein places in the commonality of the private sphere. For Stein then, it is this freedom of seclusion that enables the creation of 
art. The particular female entitlement to the private sphere would then also be the reason why "in this epoch the important literary thinking is done by a woman.” In this gesture, Hejinian is partly aligning with recent feminist critique of Arendt, taking her use of the gendered noun "men" for human beings as revealing the discriminatory nature of her concept of the public sphere, one that excludes women and any other member of society giving or requiring care or lacking leisure time. ${ }^{46}$ In the context of this article, Hejinian's claim that Stein was a non-political writer may sound somewhat bold, given that it is made about the author of a sequence of newspaper commentaries on money written in the midst of the largest economic crisis in American history, but, as mentioned, none of these texts are among Stein's most discussed pieces. Thus, Hejinian's move here is hardly controversial visà-vis the consensus of Stein scholarship. By posterity, and especially via the extensive influence of the American movement known as the Language poets to which Hejinian belongs, Stein has very much been cast as a poet of the private sphere and such a claim certainly does hold its significant amount of truth value.47 What is Tender Buttons (1914), with its verbal "still lifes" of objects, food and rooms, if not a hymn to the household sphere? And her investment in the household sphere holds true, not just in terms of it providing a favoured subject matter but in several other ways as well. Certainly, the defence of their own household sphere was vital to Stein and Alice Toklas. Situated as it was in Paris at a safe distance from the patriarchal values of the American families of both women and from American public morals, it constituted a space in which it was possible to live freely as independent women, as writers, but also as lesbians. But the secluded, non-political image of Stein is also a comfortable simplification that leaves out the many ways in which Stein indeed was a political writer, and an economic one, although of a somewhat different political observation than the language poets themselves.

While it is fairly obvious that Hejinian in this passage is simply not talking about Stein's liberalist political commentary, her claim is not entirely satisfactory for the remaining parts of Stein's work either. Stein may be defending the freedom of "a private life" with all her might, but she is also very aware of "the private being political," although in another sense than the one this expression implied for the 1960s and -70s feminist movement that coined it.

For one thing, casting Stein as a poet of the household sphere bluntly ignores the conscious blurring of the borders between private and public space that were definitional to Stein's salon 
which shared its semi-public space with her non-public household sphere, and which remains crucial to any understanding of Stein's life and work. Furthermore, as evoked in the introduction to this text, the household objects at the centre of Tender Buttons and other early works are already infected by consumer culture, the private sphere of Stein, never entirely free from money or politics. In The Human Condition, Arendt also discusses how the borders between the private and public spheres are breaking down in the modern capitalist economy based on wage labour. In the modern consumer economy, the labourer inhabits the public realm, but it is no longer a public realm in the way of the Greek polis, that is, relieved from the fulfilment of basic needs. Instead, it is an intermingling of private and public spheres, it is a mesh of "private activities displayed in the open" or, in Arendt's phrasing, simply of "mass culture." 48 This is exactly what Stein explores in Tender Buttons and the early window shopping texts that tie together public and private spaces. And it also describes her barter economy salon, rendering possible her particular sideways relationship to literature's capitalist publishing economy that secured for Stein a deliberate transport between the spheres.

This conglomeration of private activities displayed in public and public activities facilitated by private relations is not unlike Stein's characterization of the non-capitals. Surely, Stein's important wandering city of America would not make much of a Greek polis in Arendt's sense. But the breaking down of the borders between the private and the public sphere is also part of modernity's general breakdown of the order of things. And, in spite of the seemingly celebratory tone found in a piece like “The Capital or Capitals,” it troubled Stein (almost) as much as it troubled Ezra Pound.

In Arendt's analysis, money is the vehicle that secures the transportation and exchange between the spheres. This is the same reason why Pound wanted the monetary system to be controlled by the fascist leader. Since money was the medium that powered the traffic between the spheres, the implementation of a statecontrolled currency could also bring it to an end. Here, Stein takes another path. If we recall the meditations on money and art in The Geographical History, the material reality of master-pieces is what separates them from money that ultimately "has no existence." We can see why Stein in her poetry is not primarily concerned with producing an aesthetic representation of capital to compensate for its abstraction, but rather with putting money and artworks to use as parts of a material and collaborative infrastructure that turns 
literature into an economy in itself, a circulation of aesthetic value which implies the freedom of the reader to "think of something," the value of which we are affirmatively assured: "That is it [...] But yes yes/ By no means cease." Although she may not have been able to sell her work to make money in the beginning of her career, she managed to distribute it via her salon that placed itself between public and private space. But in the end, of course, the salon also existed because of money: not the money of wage labour addressed by Arendt, but the old-world money of paternal inheritance Stein used to purchase paintings.

Stein's commentaries all defend the private sphere, but they also make absolutely clear that the private sphere is infected by the public sphere all the time as it is secured by the presence of money. And in response to this condition, Stein proposes an attitude commemorating the figure of Benjamin's capitalist worshipper, that of a true "believer in money." Curiously, it appears to be Stein's enthusiasm for classic American liberalist, free-market capitalism, as it comes out most clearly in the "Money"-texts, that effectively prevents her from following the course of Pound. Although her anti-patriarchal impulses take her a good step forward, it is her adherence to capitalism that in the end saves her from fascism.

In the mid-1930s Gertrude Stein had suddenly been thrown into the modern publishing economy and experienced the estranging effects of the circulation of her writing and herself on the free market. At the same time, she was confronted with the American crisis economy where money, as we have seen, was being cut loose from the scarcity economy, the gold standard, and the patriarchal financial system of savings, interest, and inheritance that she had regularly undermined in her writings but also depended on for her sustenance, and moving rapidly towards the unpersonal, abstract, self-representational, and speculative capital of our contemporary economic paradigm. But even here, underneath the new abstract economy, she curiously identified another bourgeois patriarch to replace the old one, as she discovered that money is never just a neutral vehicle. Money may not begin or end, as she meditates in The Geographical History of America, but in times of crisis it tends to return to the father anyway. 
1 Gertrude Stein, Everybody's Autobiography (Cambridge: Exact Change, 1993), 41.

2 Michael Davidson, "The Romance of Materiality," in Ghostlier Demarcations. Modern Poetry and the Material Word (Berkeley: University of California Press, 1996), 44.

3 Sianne Ngai, Our Aesthetic Categories: Zany, Cute, Interesting (Cambridge Massachusetts: Harvard University Press, 2012), 271.

4 See Solveig Daugaard, "It might be a portrait but in any case it is for you" in Trans - Révue de littérature générale et comparée, no. 15 (2013), http://journals.openedition. org/trans/758 and Collaborating with Gertrude Stein. Media ecologies, reception, poetics, (Linköping: Linköping University Press, 2018).

5 Luke Carson, Consumption and Depression. Gertrude Stein, Louis Zukofsky and Ezra Pound (London: Macmillan Press and New York: St. Martin's Press, 1999), 60.

6 See for instance Bryce Conrad, "Gertrude Stein in the American Marketplace" in Journal of Modern Literature 19.2 (1995), Carson, Consumption and Depression, Michael Szalay, New Deal Modernism. American Literature and the Invention of the Welfare State (Durham: Duke University Press, 2000) and Kristin Grogan, “Money on My Mind: Stein's Meditations" in Dibur Literary Journal 5 (2018).

7 Braidotti acknowledges her debt to Stein's thinking in the opening of her book Nomadic Subjects, using an epigraph from Stein to start off the first chapter: "It's great to have roots, as long as you can take them with you." See Rosi Braidotti, Nomadic Subjects: Embodiment and sexual difference in contemporary feminist theory, 2nd edition (New York: Columbia University Press, 2011), 21. See also Jessica Berman, Modernist Fiction, Cosmopolitanism and the Politics of Community (Cambridge: Cambridge University Press, 2001) for an elaboration of this motif in Stein's works.

8 Enzo Traverso, "Totalitarianism between history and theory" in History and Theory, Theme Issue 55 (2017): 99.

9 Thus, making the timing of her first bestseller all the more fortunate. See Grogan, “Money on My Mind”, 13.

10 Conrad, "Gertrude Stein in the American Marketplace", 28-29.

11 Giorgio Agamben, The Kingdom and the Glory, (Stanford, Ca: Stanford University Press, 2011), xii.

12 See Walter Benjamin, "Capitalism as Religion" in Selected Writings Volume 1: 1913-1926 (Cambridge, MA: The Belknap Press of Harvard University Press, 1996), 288-291 and Giorgio Agamben, "En kommentar, i dag" in Benjamin, Kurz, Agamben Kapitalisme som religion (Aarhus: Nebula and Antipyrine, 2020), 85 (Danish translation from the Italian of "Un commento, oggi", 2013).

13 See Carson, Consumption and Depression,16-20.

14 Gertrude Stein, "A Political Series", Painted Lace and Other Pieces (1914-1937), (New Haven: Yale University Press,1955), 72.

15 Gertrude Stein, The Making of Americans. Being the History of a Family's Progress (New York: The Something Else Press, 1966), 560.
16 Gertrude Stein, Lectures in America in Writings 19321946, edited by Catherine R. Stimpson and Harriet Chessman (New York: Library of America, 1998), 324.

17 Szalay, New Deal Modernism, 89.

18 Stein, Lectures, 289.

19 Stein explains how she, sitting with her aunts, heard the same stories recounted whenever a newcomer entered the room, sometimes ten or eleven times in an afternoon. This taught her to appreciate the difference between repetition and insistence. As long as the speaker was "talking and listening at the same time", that is as long as the lively interest and attention to every detail was present both from the speaker and the listener, there was no repetition in the gossip stories, only insistence. They were fully alive and interesting every time. As she writes, "[t]his was not yet the beginning of writing but it was the beginning of knowing what there was that made there be no repetition." Stein, Lectures, 289.

20 Stein, "A Political Series", 74.

21 Gertrude Stein, The Geographical History of America Or the Relation of Human Nature to the Human Mind, in Writings 1932-1946, edited by Catherine R. Stimpson and Harriet Chessman (New York: Library of America, 1998), 438.

22 Stein, Geographical History, 369.

23 Ibid., 437.

24 Ibid., 480.

25 Ibid., 461.

26 Ibid., 480.

27 Gertrude Stein, Four Saints in Three Acts. On Opera to Be Sung in Writings 1903-1932, edited by Catherine R. Stimpson and Harriet Chessman (New York: Library of America, 1998), 614.

28 Benjamin, Capitalism, 288.

29 Stein, "A Political Series", 76.

30 Ibid., 76.

31 Ibid., 76.

32 Ulla E. Dydo, Gertrude Stein: The Language That Rises: 1923-1934 (Evanston IL: Northwestern University Press, 2003), 138.

33 Gertrude Stein, "Money" in How Writing is Written. Volume II of The Previously Uncollected Writings of Gertrude Stein, edited by Robert Bartlett Haas (Los Angeles: Black Sparrow Press, 1974), 107.

34 Gertrude Stein, "All About Money," in How Writing is Written. Volume II of The Previous/y Uncollected Writings of Gertrude Stein, edited by Robert Bartlett Haas (Los Angeles: Black Sparrow Press, 1974), 110.

35 Gertrude Stein, "Still More About Money" in How Writing is Written. Volume II of The Previously Uncollected Writings of Gertrude Stein, edited by Robert Bartlett Haas (Los Angeles: Black Sparrow Press, 1974), 109.

36 Gertrude Stein, My Last About Money" in How Writing is Written. Volume II of The Previously Uncollected Writings of Gertrude Stein, edited by Robert Bartlett Haas (Los Angeles: Black Sparrow Press, 1974), 111.

37 Stein, "My Last About Money", 111.

38 Stein, "A Political Series", 75.

39 Stein, Everybody's Autobiography, 137.

40 Stein, Geographical History, 479.

41 Ibid., 419. 
42 Ibid., 472.

43 Lyn Hejinian, "A Common Sense," in The Language of Inquiry (Berkeley: University of California Press, 2000), 365.

44 Ibid., 366.

45 Ibid., 366.

46 For critique of Arendt's concept, see for instance Judith Butler Notes Towards a Performative Theory of Assembly (Cambridge MA: Harvard University Press, 2015) and Johanna Hedva, "Sick Woman Theory," in Mask Magazine (2016) http://www.maskmagazine.com/ not-again/struggle/sick-woman-theory. Also, Stein's explicit gendering of the also often 'neutrally' male gendered figure of the literary genius, by suggesting the "important literary thinking of this epoch" as "naturally" being done by "by a woman" casts a critical feminist light on the use of "men" as an apparently gender neutral term in Arendt's work and beyond.

47 In the Stein reception from the 1970 s a tendency exists to de-politicize the content of Stein's writings while reading their aesthetic transgressions as expressions of a radical, anti-hierarchical, anti-patriarchal, and essentially anti-capitalist "politics of form." Also, the overall aesthetic argument of Michael Davidson cited above can, although he engages in unusual detail with Stein's enthusiasm for commodities, in part, be aligned with this tendency. See Daugaard, Collaborating, 153239 for elaboration.

48 Hannah Arendt, The Human Condition (2nd edition, Chicago: University of Chicago Press, 1998 [1958]), 134. 